\title{
PENGARUH UKURAN PARTIKEL DAN FERMENTASI MENGGUNAKAN Aspergillus niger YANG TELAH DIIRADIASI TERHADAP DEGRADABILITAS IN SACCO JERAMI PADI
}

\section{THE EFFECT OF PARTICLE SIZE AND FERMENTATION WITH IRRADIATED Aspergillus niger ON IN SACCO DEGRADABILITY OF RICE STRAW}

\author{
Teguh Wahyono ${ }^{1 *}$, lin Ana Rizqi ${ }^{2}$, La Ode Sumarlin ${ }^{2}$, Tri Retno Dyah Larasati ${ }^{3}$ dan \\ Suharyono ${ }^{1}$ \\ ${ }^{1}$ Bidang Pertanian, Pusat Aplikasi Isotop dan Radiasi, Badan Tenaga Nuklir Nasional, Cilandak, Jakarta \\ Selatan, 12070 \\ ${ }^{2}$ Fakultas Sains dan Teknologi, Universitas Islam Negeri Syarif Hidayatullah, Banten, 15419 \\ ${ }^{3}$ Bidang Industri dan Lingkungan, Pusat Aplikasi Isotop dan Radiasi, Badan Tenaga Nuklir Nasional, \\ Cilandak, Jakarta Selatan, 12070
}

Submitted: 18 December 2016, Accepted: 10 April 2017

\section{INTISARI}

Penelitian ini bertujuan untuk mengevaluasi nilai degradabilitas substrat pakan jerami padi secara in sacco dengan ukuran partikel yang berbeda dan perlakuan fermentasi menggunakan Aspergillus niger yang diiradiasi. Rancangan yang digunakan adalah rancangan acak lengkap (RAL) pola faktorial $2 \times 2$ dengan ukuran partikel sebagai faktor pertama dan perlakuan fermentasi sebagai faktor kedua Perlakuan penelitian adalah: 1) Jerami padi non fermentasi ukuran $5 \mathrm{~cm}$ (JP5); 2) Jerami padi non fermentasi ukuran halus (JPH); 3) Jerami padi fermentasi ukuran $5 \mathrm{~cm}$ (JP5F) dan 4) Jerami padi fermentasi ukuran halus (JPHF). Masing-masing perlakuan dibuat dalam empat ulangan. Hasil penelitian menunjukkan bahwa fermentasi dengan Aspergillus niger pada jerami padi ukuran $5 \mathrm{~cm}$ dapat meningkatkan kandungan bahan kering (BK) sebesar 2,06\% sedangkan pada jerami padi halus meningkat sebesar 2,55\%. Ukuran partikel halus meningkatkan kandungan BK jerami padi setelah difermentasi. Perlakuan fermentasi meningkatkan degradasi BK dan bahan organik (BO) jerami padi pada kedua ukuran partikel. Perbedaan ukuran partikel tidak berpengaruh nyata terhadap degradasi BK dan BO. Kesimpulan dari penelitian ini adalah bahwa fermentasi menggunakan Aspergillus niger yang telah diiradiasi dapat meningkatkan degradasi BK dan BO jerami padi. Ukuran partikel yang berbeda tidak berpengaruh nyata terhadap degradabilitas jerami padi secara in sacco.

(Kata kunci: Aspergillus niger, Degradabilitas, Fermentasi, In Sacco, Jerami padi)

\section{ABSTRACT}

This research aims to evaluate the degradability of rice straw in different particle size and after fermentation using irradiated Aspergillus niger. Experiment was designed in a 2x2 completely randomized design factorial with the particle size and fermentation treatment as first and second factor respectively. Treatments were: 1) $5 \mathrm{~cm}$ non-fermented rice straw (JP5); 2) fine size non-fermented rice straw (JPH); 3) $5 \mathrm{~cm}$ fermented rice straw (JP5F) and 4) fine size fermented rice straw (JPHF). Replication was four times. The results showed that fermentation with irradiated Aspergillus niger increased dry matter (DM) content as much as 2.06 and $2.55 \%$ for $5 \mathrm{~cm}$ and fine size of rice straw respectively. Decreasing particle size increased DM content after fermentation. Fermentation treatment increased the degradation of DM and organic matter (OM) for both particle size. Differences of particle size did not affect DM and OM degradation. It was concluded that fermentation using irradiated Aspergillus niger increase the degradation of DM and OM of rice straw. Using differences particle size did not have effect in sacco degradability of rice straw.

Key words: Aspergillus niger, Degradability, Fermentation, In Sacco, Rice straw)

\footnotetext{
${ }^{*}$ Korespondensi (corresponding author):

Telp. +62 85643420641

E-mail: teguhwahyono@batan.go.id
} 


\section{Pendahuluan}

Jerami padi saat ini merupakan pakan pokok yang lazim diberikan pada ternak di daerah sentra pertanian. Hartono dan Kurniawan (2009) melaporkan bahwa karena ketersediaannya yang melimpah, 31-32\% jerami padi dimanfaatkan sebagai pakan ternak. Kendala pemanfaatan jerami padi sebagai pakan ternak adalah kandungan serat kasar, lignin dan silika yang relatif tinggi. Hal ini dapat disebabkan karena jerami padi tersebut diperoleh dari tanaman padi yang dipanen sampai umur matang. Kandungan serat yang tinggi menyebabkan tingkat kecernaan pakan menjadi rendah. Selain itu, jerami padi juga memiliki kandungan protein kasar yang rendah.

Berbagai usaha dilakukan untuk mengatasi rendahnya nilai cerna dan meningkatkan nilai nutrisi jerami padi. Beberapa perlakuan diantaranya perlakuan fisik, kimia maupun bantuan organisme lain (biologis). Salah satu perlakuan fisik yang dilakukan untuk meningkatkan nilai degradasi adalah memperkecil ukuran partikel suatu bahan pakan. Hidayat et al. (2006) menjelaskan bahwa memperkecil ukuran partikel jerami dapat meningkatkan nilai nutrisi dan daya cerna. Ramos et al. (2009) juga melaporkan bahwa ukuran partikel biji jagung sangat mempengaruhi proses pencernaan pati di dalam rumen sehingga dapat dijadikan perlakuan dalam hal manipulasi proses fermentasi.

Berbagai riset telah dilakukan dengan menggunakan mikroba sebagai subyek yang melakukan fermentasi secara enzimatis. Pada penelitian terdahulu, Yulistiani et al. (2012) melaporkan bahwa penggunaan Aspergillus niger ( $A$. niger) dalam fermentasi tongkol jagung dapat meningkatkan degradasi bahan kering (BK) dan bahan organik (BO) masing-masing sebesar $47,2 \%$ dan $47,5 \%$. Pada penelitian lain, Prihartini et al. (2007) menggunakan isolate bakteri lignolitik TLiD dan BOpR untuk mendegradasi lignin dan meningkatkan degradasi jerami padi, sedangkan Jahromi et al. (2010) menggunakan $A$. niger (K8) untuk meningkatkan nilai nutrisi jerami padi. $A$. niger menghasilkan enzim selulase yang menghidrolisis selulosa menjadi gula yang mudah larut seperti glukosa (Devi dan Kumar, 2012). Aktivitas mikroorganisme dalam proses fermentasi dapat ditingkatkan dengan iradiasi gamma pada dosis rendah. A. niger yang dipapar pada dosis $500 \mathrm{~Gy}$ menghasilkan aktivitas enzim selulase yang tinggi dibandingkan fungi tanpa paparan iradiasi (Mulyana et al., 2015). Kombinasi ukuran partikel dan penggunaan fungi $A$. niger perlu dievaluasi lebih lanjut untuk mengetahui efektifitasnya dalam meningkatkan degradasi pakan. Tujuan penelitian ini adalah untuk mengevaluasi nilai degradabilitas jerami padi pada ukuran partikel yang berbeda dan perlakuan fermentasi menggunakan $A$. niger yang telah diiradiasi.

\section{Materi dan Metode}

\section{Preparasi jerami padi}

Jerami padi varietas Sidenuk dibersihkan dan diangin-anginkan selama dua hari. Sebagian jerami yang telah keringangin dicacah sampai ukuran $5 \mathrm{~cm}$. Sebagian lagi digiling halus menggunakan grinder pada ukuran $2 \mathrm{~mm}$. Sampel kemudian dikeringkan di dalam oven $60^{\circ} \mathrm{C}$ selama 48 jam.

\section{Rancangan percobaan}

Penelitian ini menggunakan rancangan acak lengkap (RAL) pola faktorial $2 \times 2$ dengan ukuran partikel sebagai faktor pertama dan perlakuan fermentasi sebagai faktor kedua. Setiap perlakuan dilakukan pengulangan sebanyak empat kali. Perlakuan penelitian adalah: jerami padi non fermentasi ukuran $5 \mathrm{~cm}$ (JP5), jerami padi non fermentasi ukuran halus (JPH), jerami padi fermentasi ukuran $5 \mathrm{~cm}$ (JP5F), jerami padi fermentasi ukuran halus (JPHF).

\section{Fermentasi jerami padi}

Fermentasi jerami padi dilakukan dengan menggunakan tiga komponen utama yaitu inokulum $A$. niger, larutan nutrisi dan substrat jerami padi. Pembuatan larutan nutrisi dilakukan dengan melarutkan $28,8 \mathrm{~g}$ PDB; $1,2 \mathrm{~g}\left(\mathrm{NH}_{4}\right)_{2} \mathrm{SO}_{4} ; 0,6 \mathrm{~g} \mathrm{KH}_{2} \mathrm{PO}_{4} ; 0,6 \mathrm{~g}$ $\mathrm{K}_{2} \mathrm{HPO}_{4}$ dan $0,24 \mathrm{~g} \mathrm{MgSO}_{4} .7 \mathrm{H}_{2} 0$ dalam 1200 $\mathrm{ml}$ akuades kemudian disterilkan pada autoklaf dengan suhu $121^{\circ} \mathrm{C}$ selama 15 menit. Inokulum yang digunakan adalah $A$. niger yang telah diiradiasi gamma pada dosis 500 Gy. Iradiasi gamma menggunakan sumber Co-60 di Fasilitas iradiator Pusat Aplikasi Isotop dan Radiasi. Sebanyak 200 $\mathrm{ml}$ larutan nutrisi dan $10 \mathrm{~g}$ inokulum dilarutkan ke dalam $200 \mathrm{ml}$ akuades. Larutan dicampur dengan $200 \mathrm{~g}$ substrat jerami padi. Substrat diinkubasi di dalam kantong plastik berukuran $5 \mathrm{~kg}$ dan ditutup rapat dengan 
pipa yang disumbat kapas. Plastik inkubator kemudian dilapisi kain kasa kemudian ditutup plastik dan diikat. Inkubasi dilakukan selama 15 hari.

\section{Analisis sampel}

Jerami padi non fermentasi dan jerami padi fermentasi baik yang berukuran $5 \mathrm{~cm}$ maupun halus dikeringkan pada oven $60^{\circ} \mathrm{C}$ selama 48 jam. Sampel kemudian dianalisis kadar bahan kering (BK), abu, protein kasar (PK) dan lemak kasar (LK) (AOAC, 2010). Neutral detergent fiber (NDF) dan acid detergent fiber (ADF) juga dianalisis menggunakan prosedur Goering dan Van Soest (1970).

\section{Evaluasi in sacco}

Pengujian in sacco dilakukan dengan metode Ørskov dan McDonald (1979) cit. Krishnamoorthy (2001). Ternak yang digunakan adalah kerbau jantan berfistula berat badan $350 \mathrm{~kg}$ yang dipelihara dalam kandang individu berukuran $5 \times 3 \mathrm{~m}^{2}$. Kandang menggunakan lantai semen yang dibersihkan secara berkala. Ransum seharihari diberikan sesuai kebutuhan berat badan kerbau. Komposisi ransum kerbau berupa rumput lapangan (70\%) dan konsentrat $(30 \%)$ dalam BK. Komposisi konsentrat terdiri dari bungkil kedelai $(9 \%)$, onggok $(39 \%)$, dedak $(28,5 \%)$, ampas kecap $(15 \%)$, laktamineral $(2 \%)$, urea $(1,5 \%)$, garam $(1 \%)$, kapur $(1,5 \%)$ dan molasses $(2,5 \%)$.

Kantong nilon berukuran $7 \times 12 \mathrm{~cm}$ dengan ukuran pori-pori $20 \mu \mathrm{m}$ diisi sampel sebanyak $5 \mathrm{~g}$. Kantong nilon yang telah berisi sampel dimasukkan ke dalam rumen melalui fistula sebelum kerbau diberi pakan pada pagi hari (08.00 WIB). Inkubasi dilakukan pada periode 0, 6, 12, 24, 48 dan 72 jam. Sampel yang telah diinkubasi kemudian dibilas dan diangin anginkan. Sampel dikeringkan kembali dalam oven suhu $60^{\circ} \mathrm{C}$ selama 48 jam untuk memperoleh berat BK. Peubah yang diamati adalah degradasi BK dan degradasi BO. Produk fermentasi rumen berupa konsentrasi $\mathrm{NH}_{3}$, produksi VFA (volatile fatty acids) total dan kondisi $\mathrm{pH}$ juga diukur pada masing-masing waktu inkubasi. Pengukuran $\mathrm{NH}_{3}$ menggunakan metode mikrodifusi Conway (Conway, 1950), pengukuran VFA total berdasar metode AOAC (2010) sedangkan pengukuran $\mathrm{pH}$ menggunakan $\mathrm{pH}$ meter Hanna instrument.

\section{Analisis statistik}

Pengaruh perlakuan dianalisis menggunakan program SPSS 16.00 dilanjutkan dengan uji Duncan's multiple range test (DMRT) (Steel and Torrie, 1980) untuk melihat perbedaan antar perlakuan.

\section{Hasil dan Pembahasan}

\section{Komposisi kimia}

Hasil analisis kandungan nutrisi substrat pakan penelitian disajikan pada Tabel 1. Jerami padi yang difermentasi menghasilkan kandungan BK lebih tinggi dibandingkan sebelum difermentasi. Pada jerami padi ukuran $5 \mathrm{~cm}$ (JP5), fermentasi meningkatkan kandungan $\mathrm{BK}$ sebesar 2,06\% $(\mathrm{P}<0,05)$. Pada jerami padi halus $(\mathrm{JPH})$, kandungan BK meningkat 2,55\% setelah difermentasi $(P<0,05)$. Ukuran partikel tidak berpengaruh terhadap kandungan BK pada jerami padi yang belum difermentasi, namun berpengaruh nyata setelah perlakuan fermentasi $(P<0,05)$. Kandungan $P K$ perlakuan JP5F juga lebih tinggi dibandingkan JP5. Peningkatan PK pada jerami padi ukuran $5 \mathrm{~cm}$ setelah difermentasi menjadi lebih tinggi $111 \% \quad(\mathrm{P}<0,05)$. Kandungan PK Jerami padi halus (JPH) juga meningkat $20,78 \%$ setelah difermentasi, namun secara statistik tidak berbeda nyata. Ukuran partikel tidak berpengaruh terhadap perubahan kandungan PK baik pada jerami padi sebelum dan sesudah fermentasi. Keempat perlakuan tidak menunjukkan perbedaan yang nyata terhadap peubah BO, LK, NDF dan ADF.

Peningkatan kandungan BK pada jerami padi akibat perlakuan fermentasi, baik pada ukuran partikel $5 \mathrm{~cm}$ maupun halus disebabkan oleh berkurangnya kadar air selama proses fermentasi. Unsur air digunakan sebagai media tumbuh kapang $A$. niger sehingga kandungannya semakin berkurang. Peningkatan kandungan nutrisi BK sebagai akibat degradasi selulosa oleh inokulum $A$. niger. Hal tersebut dipengaruhi oleh penambahan berat akibat pertumbuhan kapang. Ketersediaan energi dan nutrien setelah proses fermentasi akan meningkatkan pertumbuhan kapang sehingga dapat menambah kadar BK. McDonald et al. (1991) melaporkan bahwa pemecahan karbohidrat oleh mikroba akan diiringi oleh hilangnya energi dalam bentuk panas, $\mathrm{CO}_{2}$ dan air. Peningkatan kandungan 
PK juga disebabkan oleh mekanisme yang sama seperti peningkatan kandungan BK. Degradasi ikatan kompleks nutrien juga menghasilkan nutrien yang sebelumnya saling terikat diantaranya nitrogen, mineral dan residu pestisida sehingga kandungan PK akan meningkat. Peningkatan pertumbuhan kapang juga menambah kandungan protein pada jerami padi hasil fermentasi. Hasil penelitian ini sesuai dengan penelitian Jahromi et al. (2010) yang melaporkan bahwa perlakuan fermentasi pada jerami padi yang ditambahkan inokulum $A$. niger (K8) selama 10 hari mampu meningkatkan kadar PK. Yanti et al. (2008) juga menjelaskan bahwa perubahan kadar PK jerami padi yang difermentasi dipengaruhi oleh aktivitas mikroorganisme di dalamnya.

Perlakuan fermentasi tidak berpengaruh nyata terhadap kandungan BO, LK, NDF dan ADF. Namun secara numerik, kandungan $\mathrm{BO}$ menurun setelah perlakuan fermentasi. Hal tersebut dapat disebabkan oleh kandungan bahan organik jerami padi semakin berkurang karena digunakan oleh inokulum $A$. niger selama proses fermentasi. Jahromi et al. (2010) menjelaskan bahwa fermentasi menggunakan $A$. niger selama 10 hari menurunkan kandungan $\mathrm{BO}$ jerami padi. Penurunan disebabkan oleh adanya aktivitas biologis inokulum terhadap nutrien yang terkandung dalam substrat. Stokes dan Chen (1994) melaporkan bahwa penambahan enzim selulase komersial dalam pembuatan silase tanaman jagung dapat menurunkan kandungan BO silase yang dihasilkan. Perlakuan fermentasi tidak memberikan pengaruh nyata terhadap penurunan NDF dan ADF. Namun demikian terlihat kecenderungan terhadap peningkatan nilai NDF dan ADF setelah fermentasi. Hal tersebut merepresentasikan bahwa kinerja inokulum juga dipengaruhi oleh kondisi substrat jerami padi yang difermentasi. Semakin tua umur panen jerami padi yang digunakan akan menghambat proses fermentasi karena faktor lignin sebagai penghambat.

Perlakuan fermentasi pada jerami padi ukuran partikel halus menghasilkan kandungan BK yang lebih tinggi dibandingkan hasil fermentasi ukuran partikel 5 cm. Hal tersebut dapat disebabkan oleh efektifitas pendegradasian BK selama proses fermentasi lebih baik pada luas permukaan besar atau ukuran partikel halus. Ukuran partikel substrat yang lebih kecil akan meningkatkan kontak antara sel jamur terutama miseliumnya dengan substrat sehingga dapat meningkatkan aktivitas enzim selulase (Wulandari et al., 2014). Pada variabel kandungan nutrisi selain BK, particle size tidak berpengaruh dan tidak berinteraksi dengan perlakuan fermentasi. Hal tersebut karena $A$. niger memiliki aktivitas yang tinggi setelah diiradiasi 500 Gy (Mulyana et al., 2015) sehingga inokulum tetap akan bekerja tanpa banyak dipengaruhi oleh ukuran partikel. Namun pernyataan ini perlu didukung uji aktifitas selulase yang dihasilkan $A$. niger. Hal tersebut untuk mengetahui pengaruh ukuran partikel terhadap aktivitas enzim selulase selama fermentasi.

\section{Degradasi BK}

Hasil degradasi BK secara in sacco dapat dilihat pada Tabel 2. Keempat perlakuan tidak menunjukkan perbedaan degradasi BK $(P<0,05)$ sebesar $51,80 \%$ pada jerami padi ukuran $5 \mathrm{~cm}$. Pada jerami halus, fermentasi jerami padi dapat meningkatkan degradasi BK sebesar 51,93\% $(P<0,05)$. Persentase peningkatan tersebut merupakan hasil perhitungan perbandingan antara perlakuan jerami yang difermentasi

Tabel 1. Kandungan nutrisi sampel perlakuan

(nutrient composition of treatments sample)

\begin{tabular}{|c|c|c|c|c|c|c|}
\hline \multirow{2}{*}{$\begin{array}{l}\text { Perlakuan } \\
\text { (treatments) }\end{array}$} & \multicolumn{6}{|c|}{ Kandungan nutrisi (\%) (nutrient composition (\%)) } \\
\hline & $\begin{array}{c}\text { Bahan kering } \\
\text { (dry matter) }\end{array}$ & $\begin{array}{l}\text { Bahan organik } \\
\text { (organic matter) }\end{array}$ & $\begin{array}{l}\text { Protein } \\
\text { kasar (crude } \\
\text { protein) }\end{array}$ & $\begin{array}{c}\text { Lemak kasar } \\
\text { (ether } \\
\text { extract) }\end{array}$ & $\begin{array}{c}\text { NDF } \\
\text { (neutral detergent } \\
\text { fiber) }\end{array}$ & $\begin{array}{c}\text { ADF } \\
\text { (acid detergent } \\
\text { fiber) }\end{array}$ \\
\hline $\mathrm{JP}$ & & & $1,78 \pm 0,78^{a}$ & & & $66.21+7.21$ \\
\hline & & & & & & \\
\hline $25 \mathrm{~F}$ & $a^{b}$ & $78, \varepsilon$ & & & & $2 \pm 2$ \\
\hline JPHF & $95,38 \pm 0,14^{c}$ & $77,87 \pm 0,14$ & $2,50 \pm 0,73^{a b}$ & & $: 3,32$ & $70,51 \pm 3,38$ \\
\hline \multicolumn{7}{|c|}{$\begin{array}{l}\text { JP5: jerami padi non fermentasi ukuran } 5 \mathrm{~cm}(5 \mathrm{~cm} \text { non-fermented rice straw); JPH: jerami padi non fermentasi ukuran } \\
\text { halus (fine size non-fermented rice straw); JP5F: jerami padi fermentasi ukuran } 5 \mathrm{~cm}(5 \mathrm{~cm} \text { fermented rice straw); } \\
\text { JPHF: jerami padi fermentasi ukuran halus (fine size fermented rice straw). } \\
\text { a,b,c Superscript berbeda pada kolom yang sama menunjukkan perbedaan yang nyata }(p<0,05)(\text { different superscripts at } \\
\text { the same column indicate significant differences }(p<0.05)) \text {. }\end{array}$} \\
\hline
\end{tabular}


Tabel 2. Degradasi BK (\%) pakan perlakuan yang diinkubasi pada waktu yang berbeda (DM degradation of feed treatments with different times incubation)

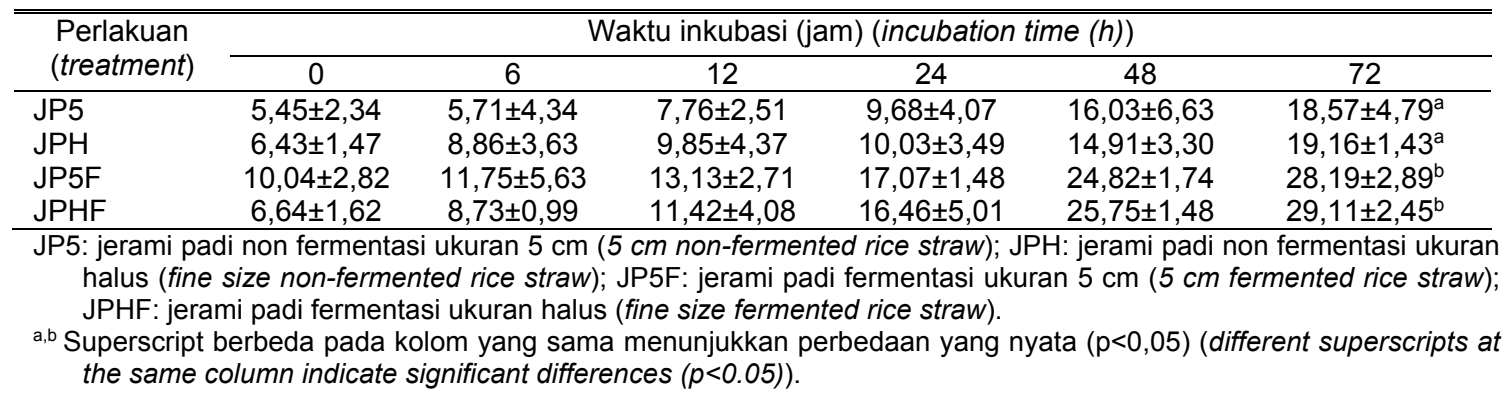

dengan yang tidak. Perbedaan ukuran partikel tidak berpengaruh nyata terhadap degradasi BK baik pada jerami padi halus maupun ukuran $5 \mathrm{~cm}$. Pada peubah degradasi BK tidak terdapat interaksi antara ukuran partikel dengan perlakuan fermentasi.

Peningkatan degradasi BK jerami padi setelah perlakuan fermentasi disebabkan oleh ketersediaan BK yang meningkat setelah proses fermentasi (Tabel 1). Peningkatan ketersediaan nutrien pasca proses fermentasi akan meningkatkan proses degradasi oleh mikroba rumen. Dinding sel pada jerami padi lebih mudah didegradasi pasca fermentasi akibat pengaruh enzim selulase dan xylanase yang dihasilkan $A$. niger. Inokulum $A$. niger yang diiradiasi 500 Gy mampu meningkatkan aktifitas enzim yang dihasilkan sehingga perbedaan ukuran partikel tidak berpengaruh terhadap degradasi BK. Mulyana et al. (2015) melaporkan bahwa aktivitas selulase A. niger meningkat 3,9 kali setelah diiradiasi gamma pada dosis $500 \mathrm{~Gy}$. Hasil penelitian ini sejalan dengan penelitian Lee et al. (2014) yang menggunakan fungi anaerob sebagai starter silase jerami padi. Dalam penelitian tersebut, degradasi BK meningkat setelah proses silase menggunakan inokulum Piromyces M014, Orpinomyces
R001 dan Neocallimastix M010. Semaun dan Rahmawati (2013) juga melaporkan bahwa penggunaan $A$. niger sebagai starter pembuatan silase jerami jagung menghasilkan kecernaan BK in vitro yang lebih tinggi dibandingkan kontrol (tanpa silase). Mekanisme peningkatan degradasi BK dipengaruhi oleh semakin meningkatnya ketersediaan protein pada jerami fermentasi (Tabel 1). Fungi $A$. niger adalah sumber protein yang langsung dapat dimanfaatkan oleh mikroba rumen.

\section{Degradasi BO}

Tabel 3 menunjukkan bahwa tidak terdapat perbedaan yang nyata pada keempat substrat perlakuan selama inkubasi ke 0 sampai 48 jam. Karakteristik perubahan degradasi BO terlihat seperti pada degradasi BK, yaitu baru terjadi pada jam inkubasi ke 72. Pada jerami halus, fermentasi jerami padi dapat meningkatkan degradasi BO sebesar 41,99\% ( $P<0,05)$. Pada jerami padi ukuran 5 $\mathrm{cm}$, perlakuan fermentasi meningkatkan degradasi $\mathrm{BO}$ sebesar $30,62 \%$ namun tidak berbeda nyata antar perlakuan. Perbedaan ukuran partikel juga tidak berpengaruh nyata terhadap degradasi BO baik pada jerami padi halus maupun ukuran $5 \mathrm{~cm}$. Tidak terdapat

Tabel 3. Degradasi BO (\%) pakan perlakuan yang diinkubasi pada waktu yang berbeda (OM degradation of feed treatments with different incubation times)

\begin{tabular}{|c|c|c|c|c|c|c|}
\hline \multirow{2}{*}{$\begin{array}{c}\text { Perlakuan } \\
\text { (treatment) }\end{array}$} & \multicolumn{6}{|c|}{ Waktu Inkubasi (jam) (incubation time (h)) } \\
\hline & 0 & 6 & 12 & 24 & 48 & 72 \\
\hline JP5 & $7,69 \pm 2,51$ & $9,68 \pm 3,04$ & $10,10 \pm 3,09$ & $14,46 \pm 3,28$ & $22,42 \pm 5,22$ & $22,60 \pm 6,19^{a b}$ \\
\hline JPH & $3,93 \pm 1,74$ & $5,39 \pm 3,31$ & $7,04 \pm 4,23$ & $10,46 \pm 5,85$ & $19,34 \pm 3,93$ & $21,17 \pm 0,75^{a}$ \\
\hline JP5F & $9,86 \pm 8,04$ & $10,01 \pm 1,74$ & $11,01 \pm 1,30$ & $17,81 \pm 6,00$ & $27,46 \pm 4,33$ & $29,52 \pm 5,80^{b}$ \\
\hline JPHF & $4,00 \pm 1,90$ & $6,12 \pm 2,18$ & $10,01 \pm 3,35$ & $14,69 \pm 6,33$ & $22,94 \pm 2,48$ & $30,06 \pm 3,10^{b}$ \\
\hline $\begin{array}{l}\text { JP5: jerami pa } \\
\text { halus (fine } \\
\text { JPHF: jera }\end{array}$ & di fermentas & kuran halus & size fermente & straw). & $\begin{array}{l}\text { ami padi non } \\
\mathrm{cm}(5 \mathrm{~cm} \text { ferr }\end{array}$ & $\begin{array}{l}\text { rmentasi ukura } \\
\text { nted rice strav }\end{array}$ \\
\hline
\end{tabular}


interaksi antara ukuran partikel dengan perlakuan fermentasi.

Peningkatan degradasi BO setelah fermentasi relevan dengan peningkatan degradasi BK sebagaimana tertera pada Tabel 2. Hal ini membuktikan bahwa ketersediaan nutrien yang lebih mudah dicerna pasca fermentasi berpengaruh terhadap tingkat degradasi $\mathrm{BO}$ oleh mikroba rumen. Pertumbuhan $A$. niger selama proses fermentasi juga menyumbang ketersediaan enzim yang membantu proses degradasi BO di dalam rumen. Mulyana et al. (2015) menjelaskan bahwa $A$. niger yang diiradiasi gamma 500 Gy memiliki aktivitas selulase dan produksi glukosa yang tinggi (3,9 kali dari $A$. niger non iradiasi) sehingga dapat meningkatkan kualitas jerami padi fermentasi. Pada penelitian Semaun dan Rahmawati (2013) juga disebutkan bahwa penambahan $A$. niger pada substrat pakan mampu meningkatkan degradasi $\mathrm{BO}$ secara in vitro. Ketersediaan $A$. niger dalam substrat pakan juga meningkatkan ketersediaan protein sel tunggal sehingga dapat memacu degradabilitas di rumen. Perbedaan ukuran partikel tidak berpengaruh terhadap tingkat degradasi $\mathrm{BO}$. Hal tersebut relevan dengan hasil pengukuran degradasi BK di mana $A$. niger yang telah diiradiasi 500 Gy memiliki aktifitas yang tinggi sehingga ukuran partikel tidak menimbulkan perbedaan berarti. Hal tersebut bertentangan dengan pendapat Quinantar et al. (2012) yang melaporkan bahwa peningkatan aktivitas enzim pada biomassa disebabkan oleh ketersediaan substrat pada ukuran partikel yang lebih kecil. Perbedaan hasil ini dapat disebabkan oleh perbedaan perlakuan terhadap inokulum organisme sebelum proses fermentasi. Perbedaannya adalah dalam penelitian ini dilakukan iradiasi gamma untuk meningkatkan aktivitas enzim selulase produksi $A$. niger.

\section{Karakteristik cairan rumen}

Dinamika karakteristik cairan rumen berupa nilai $\mathrm{pH}$, konsentrasi $\mathrm{NH}_{3}$ dan VFA total tertera pada Gambar 1. Dinamika nilai $\mathrm{pH}$ cenderung menurun pada waktu inkubasi jam ke 12. Pada waktu inkubasi jam ke 24-72 cenderung stabil yaitu pada kisaran 6,656,88. Konsentrasi $\mathrm{NH}_{3}$ dan produksi VFA total cenderung fluktuatif pada keenam titik pengukuran waktu inkubasi. Konsentrasi $\mathrm{NH}_{3}$ terendah terdapat pada waktu inkubasi jam

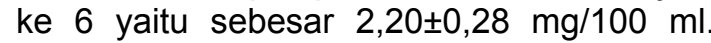

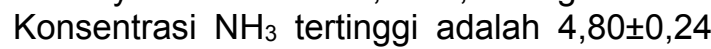
$\mathrm{mg} / 100 \mathrm{ml}$ yang terjadi pada waktu inkubasi jam ke 24. Produksi VFA total tertinggi adalah 134,62 $\pm 2,95 \mathrm{mM}$ yang terjadi pada waktu inkubasi jam ke 72 Produksi VFA total terendah terjadi pada waktu inkubasi jam ke 6 yaitu sebesar

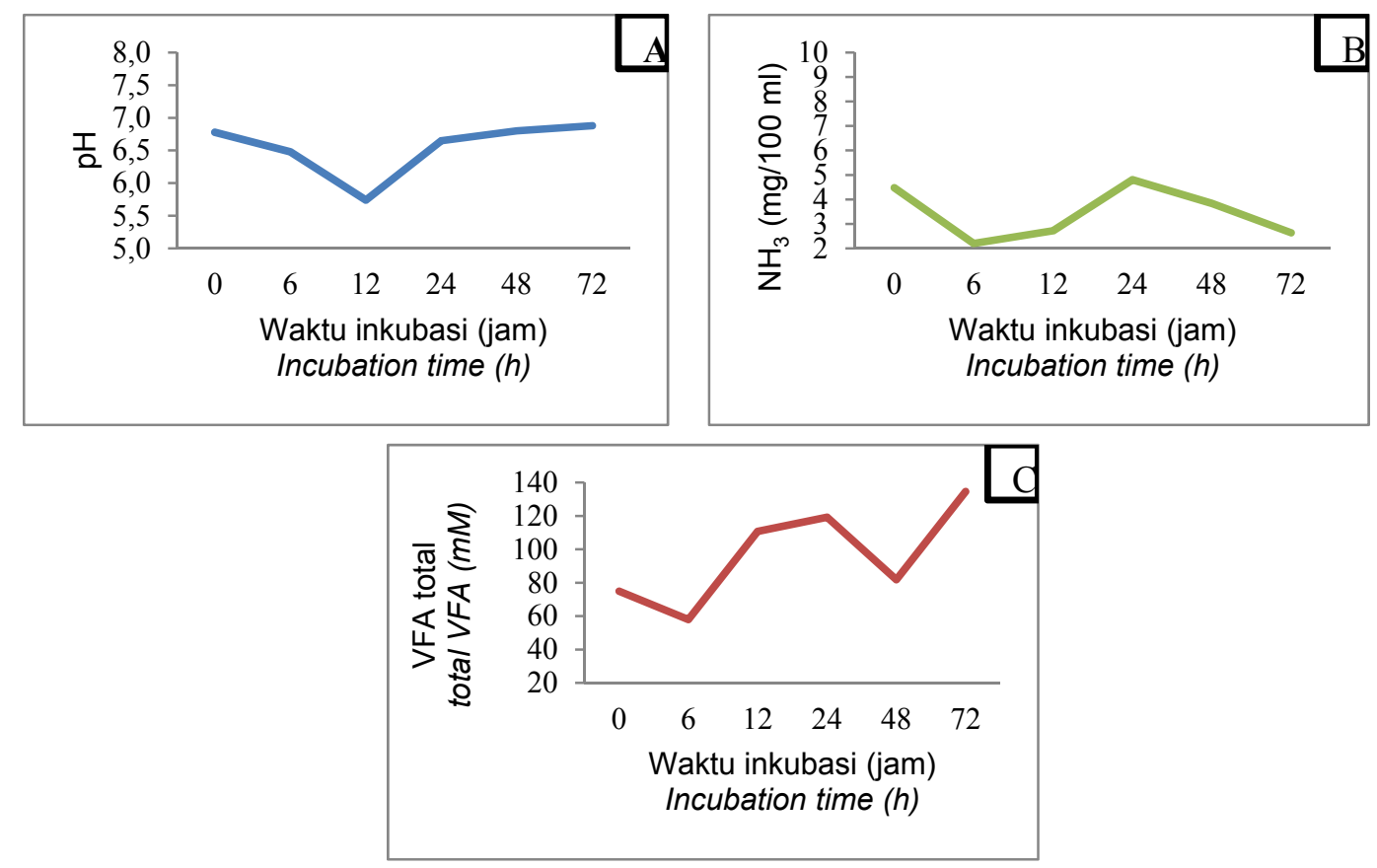

Gambar 1. Karakteristik fermentasi rumen pada waktu inkubasi yang berbeda (rumen fermentation characteristics on different incubation times). (A) $\mathrm{pH}$; (B) $\mathrm{NH}_{3}$; (C) VFA total. 
$57,64 \pm 11,81 \mathrm{mM}$. Karakteristik cairan rumen yang diamati tidak merepresentasikan pengaruh perlakuan penelitian. Pengamatan berdasarkan pada kinerja fermentasi cairan rumen akibat penambahan jerami yang bervariasi selama pengamatan in sacco berlangsung.

Nilai $\mathrm{pH}$ selama inkubasi sampel perlakuan berada dalam kisaran netral dan cenderung stabil. Hal ini sesuai dengan penelitian Nuswantara (2009) yang melaporkan bahwa kerbau yang diberi pakan hijauan tunggal baik berupa legume maupun rumput menghasilkan $\mathrm{pH}$ rumen antara 6,957,35. Nagaraja dan Titgenmeyer (2007) juga menjelaskan bahwa $\mathrm{pH}$ rumen ternak yang diberi pakan dominan biji-bijian berkisar antara 5,8-6,5. Nilai $\mathrm{pH}$ yang tidak stabil akan menyebabkan terganggunya aktivitas mikroba rumen kerbau sehingga produkproduk VFA, $\mathrm{NH}_{3}$ maupun degradasi nutrien pakan akan menurun. Konsentrasi $\mathrm{NH}_{3}$ yang terbentuk selama inkubasi berkisar antara 2,2-4.8 mg/100 ml. Hasil yang diperoleh lebih rendah dari konsentrasi optimal $\mathrm{NH}_{3}$ untuk kultur sistem tertutup yaitu berkisar $5 \mathrm{mg} / 100$ $\mathrm{ml}$ (Wanapat et al., 2013). Hal tersebut dapat disebabkan oleh rendahnya ketersediaan protein (Tabel 1) serta tingkat degradabilitas pada substrat yang diinkubasi. Produksi VFA total yang diperoleh berada pada kisaran $57,64-134,62 \mathrm{mM}$. Nilai yang diperoleh berada pada kisaran yang tinggi. Produksi VFA total rumen kerbau rawa yang diberi pakan sorgum sebagai pakan tunggal adalah $53.3 \mathrm{mM}$. Rumen kerbau yang diberi pakan jerami padi, jerami padi fermentasi dan konsentrat menghasilkan konsentrasi VFA total berturut-turut sebesar 44.8, 48.9 dan $55.9 \mathrm{mM}$ (Chanthakhoun dan Wanapat, 2012). Tingginya produksi VFA total dapat disebabkan oleh adanya kultur $A$. niger yang mampu meningkatkan degradasi pakan. Produksi VFA merupakan refleksi dari meningkatnya populasi mikroba rumen yang berkorelasi dengan laju fermentasi (Pamungkas et al., 2006).

\section{Kesimpulan}

Fermentasi dengan $A$. niger yang telah diiradiasi pada jerami padi ukuran $5 \mathrm{~cm}$ dapat meningkatkan kandungan BK sebesar $2,06 \%$ sedangkan pada jerami padi halus meningkat sebesar $2,55 \%$. Ukuran partikel halus meningkatkan kandungan BK jerami padi setelah difermentasi. Kandungan PK pada jerami padi ukuran $5 \mathrm{~cm}$ setelah difermentasi menjadi lebih tinggi $111 \%$. Ukuran partikel tidak berpengaruh nyata terhadap kandungan PK jerami padi sebelum dan sesudah fermentasi. Perlakuan fermentasi meningkatkan degradasi BK dan BO jerami padi pada kedua ukuran partikel. Peningkatan tersebut baru terlihat pada waktu inkubasi 72 jam. Perbedaan ukuran partikel tidak berpengaruh nyata terhadap degradasi BK dan BO baik pada jerami padi halus maupun ukuran $5 \mathrm{~cm}$.

\section{Ucapan Terima Kasih}

Penulis mengucapkan terima kasih kepada Nana Mulyana, SST., Shintia Nugraheni Wahyu Hardani, A.Md dan Bapak Dedi Ansori atas bantuan teknis yang diberikan selama penelitian. Penelitian ini dibiayai oleh dana riset DIPA anggaran PAIR BATAN 2016.

\section{Daftar Pustaka}

AOAC. 2010. Official Methods of Analysis of AOAC International. $18^{\text {th }}$ edn. Revision 3. Association of Official Analytical Chemist, Washington DC.

Chanthakhoun, V. and M. Wanapat. 2012. The in vitro gas production and ruminal fermentation of various feeds using rumen liquor from swamp buffalo and cattle. Asian J. Anim. Vet. Adv. 7: 5460.

Conway, E. J. 1950. Micro-diffusion Analysis and Volumetric Error. Lockwood, London.

Devi, M. C. and M. S. Kumar. 2012. Production, optimization and partial purification of cellulase by Aspergillus niger fermented with paper and timber sawmill industrial wastes. J. Microbiol. Biotech. Res. 2: 120-128.

Goering, H. K. and P. J. Van Soest. 1970. Forage Fibre Analysis (apparatus, reagents, procedures, and some application). Agric. Handbook 379, ARS. USDA, Washington, DC. USA.

Hartono, R. dan T. Kurniawan. 2009. Produksi biogas dari jerami padi dengan penambahan kotoran kerbau. Prosiding Seminar Nasional Teknik Kimia Indonesia- SNTKI, Bandung, 1920 Oktober 2009. 
Hidayat, M., Harjono, Marsudi, dan W. Gunanto. 2006. Evaluasi kinerja teknis mesin pencacah hijauan pakan ternak. Jurnal Enjiniring Pertanian 4: 61-64.

Jahromi, M. F., J. B. Liang, M. Rosfarizan, Y. M. Goh, P. Shokryazdan and Y. W. Ho. 2010. Effects of Aspergillus niger (K8) on nutritive value of rice straw. Afr. J. Biotechnol. 9: 7043-7047.

Krishnamoorthy, U. 2001. RCA Training Workshop on In Vitro Techniques for Feed Evaluation. The International Atomic Energy Agency, Jakarta, April $23-27^{\text {th }} 2001$.

Lee, S. M., L. L. Guan, J. S. Eun, C. H. Kim, S. J. Lee, E. T. Kim and S. S. Lee. 2014. The effect of anaerobic fungal inoculation on the fermentation characteristics of rice straw silages. J. App. Microbiol. 118: 565-573.

McDonald, P., A. P. Henderson and S. J. E. Heron. 1991. The Biochemistry of Silage. $\quad 2^{\text {nd }}$ edn, Chalcombe Publication.

Mulyana, N., T. R. D. Larasati, Nurhasni, dan M. Ningrum. 2015. Peningkatan aktivias enzim selulase dan produksi glukosa melalui fermenasi substrat jerami padi dengan fungi Aspergillus niger ang dipapar sinar gamma. Jurnal IImiah Aplikasi Isotop dan Radiasi 11: 13-25.

Nagaraja, T. G. and E. C. Titgemeyer. 2007. Ruminal acidosis in beef cattle: the current microbiological and nutritional outlook. J. Dairy Sci. 90: 17-38.

Nuswantara, L. K. 2009. Parameter fermentasi rumen pada kerbau yang diberi pakan tunggal glirisidia, jerami jagung dan kaliandra. Seminar Nasional Kebangkitan Peternakan Semarang, 20 Mei 2009.

Pamungkas, D., C. C. Sevilla and U. M. Lustria. 2006. Changes in rumen ecosystem and feed dry matter degradability of buffalo which received rumen content of cattle through cross inoculation. Jurnal IImu Ternak Veteriner 11: 24-33.

Prihartini, I., S. Chuzaemi and O. Sofjan. 2007. Parameter fermentasi rumen dan produksi gas in vitro jerami padi hasil fermentasi inoculum lignochloritik. Jurnal Protein 15: 24-32.

Quinantar, G. S., A. C. Ainhoa, Y. M. Flores, R. J. N. Gracida and T. J. Alejandro. 2012. Effect of particle size and aeration on the biological delignification of corn straw using Trametes sp. 44. J. Bioresour. 7: 324327.

Ramos, B. M. O., M. Champion, C. Poncet, I. Y. Mizubuti and P. Noziere. 2009. Effect of vitreousness and particle size of maize grain on ruminal intestinal in sacco degradation of dry matter, starch and nitrogen. Anim. Feed Sci. Technol. 148: 253-266.

Semaun dan Rahmawati. 2013. Kecernaan in-vitro kombinasi fermentasi jerami jagung dan dedak kasar dengan penambahan Aspergillus niger. Jurnal Galung Tropika 2: 97-102.

Steel, R. G. D. and J. H. Torrie. 1980. Principles and Procedures of Statistics. $2^{\text {nd }}$ edn. McGraw-Hill, New York.

Stokes, M. R. and J. Chen. 1994. Effect of enzyme-inoculant mixture on the course of fermentation of corn silage. J. Dairy Sci. 77: 3401-3409.

Wanapat, M., S. Kang and K. Phesatcha. 2013. Enhancing buffalo production efficiency through rumen manipulation and nutrition. Buffalo Bull. 32: 258-275.

Wulandari, A. P., E. Wulandini, dan I. Indrawati. 2014. Biodegradasi jerami padi oleh Penicillium spp. dengan variasi ukuran partikel jerami. Jurnal Selulosa 4: 107-113.

Yanti, Y., B. Rahmi, T. Miyagi, S. Mizumachi, Surahmanto, Y. Kawamoto, dan A. Purnomoadi. 2008. Nilai nutrisi jerami padi yang difermentasi dengan mikroorganisme pada suhu yang berbeda. Seminar Nasional Teknologi Peternakan dan Veteriner, Bogor, Indonesia.

Yulistiani, D., W. Puastuti, E. Wina, dan Supriati. 2012. Pengaruh berbagai pengolahan terhadap nilai nutrisi tongkol jagung: komposisi kimia dan kecernaan in vitro. Jurnal IImu Ternak Veteriner 17: 59-66. 